\section{Equity and systems of intergenerational transfers in Latin America and the Caribbean}

\author{
Martha Pelaez ${ }^{1}$ \\ and Iveris Martinez ${ }^{1}$
}

Any analysis of equity must include a consideration of intergenerational transfers in society. In this piece we will discuss these transfers within the context of rapid population aging in Latin America and the Caribbean. There are two main types of intergenerational exchanges: 1) intrafamilial transfers and 2) formal intercohort transfers. Along with personal savings and other assets, these two mechanisms can affect the cycle of work and retirement. In theory, individuals plan and save during their working years in order to accumulate enough assets for their years of retirement and/or disability. If the work period has been too short or the work income too low, however, individuals will generally need other assets to support themselves during their nonworking years. Intrafamilial intergenerational transfers involve direct transfers from one generation to another via family connections. Family ties secure the claims of one group of individuals on the goods or services produced and delivered by other family members. When the family is unable to produce sufficient goods or services to meet the demands of all family members, then family assets have to be augmented. In addition to the transfer of goods and services, these intrafamilial transfers include emotional and moral support, personal companionship, and other intangibles. The mechanisms for these intrafamilial transfers are not always stated explicitly. Instead, the mechanisms are frequently worked out according to the availability of kin and the expectations of how limited resources are to be distributed among generations within a family. In the case of poor families, the balance is often tilted in favor of the younger generation, and the burden of old age care becomes a major stress if there is not additional support from the broader society.

The second intergenerational transfer mechanism consists of formal intercohort transfers via State-mediated institutions, primarily through taxation and other income redistribution schemes. These transfers are regulated by explicit laws and enforced by government agencies. When resources at the national level are insufficient to meet the needs of all generations and the number of working-age persons contributing to the pool of resources is relatively small, the distribution of resources raises important ethical questions regarding equity.

In most societies, economic support of the "nonworking" members of society (usually children 
and elders) draws from a combination of three elements: personal savings, intrafamilial transfers, and formal intercohort transfers. Traditionally in Latin America and the Caribbean, the expectations have been that intrafamilial transfers will play the leading role in meeting the economic and social needs of the vast majority of elders. In contrast, personal savings and such formal intercohort transfers as pension programs are expected to meet the needs of a very small percentage of the older population.

Since elders make up a modest share of the population in most of the countries of Latin America and the Caribbean, the generational equity dialogue has not gained full prominence, and the rights and interests of this growing segment of the population are often excluded from the political and economic agendas of those nations. Nevertheless, the issue of intergenerational transfers and equity in Latin America and the Caribbean will become one of the most important concerns in the first decades of this century.

\section{RAPID GROWTH IN POPULATION AGING}

Population aging in Latin America and the Caribbean (LAC) is the result of public health successes that decreased infant mortality during the decade of the 1940s, when fertility levels were high. This was followed by sharp decreases in fertility during the 1970s and increases in life expectancy at age 60 during the 1990s (1). In the LAC countries the number of persons aged 60 years and over is projected to increase at an annual rate of 3.5\% during the first quarter of this century. This is three times the rate of increase for the total population. The percentage of persons 60 years and older in the total population will increase from the current $8 \%$ to $14 \%$ in the year 2025 and to $23 \%$ in 2050 . In absolute numbers, the population aged 60 years and older will rise from 42 million in the year 2000 to some 97 million in 2025 and to 181 million in 2050 (2).

This growth in the older adult population will have an unprecedented impact on all sectors of society in the LAC nations. This is especially true in terms of the need for health and social services, including noncontributory pensions and other economic protections for old age. The effects of the decreased fertility and the increased longevity are already reflected in the estimated ratio of available caregivers. The ratio of adult kin who are potentially available to provide care and services to older persons over time is projected to fall to 3.1 by 2020, a sharp decline from the ratio of 4.8 prevalent during the second half of the 20th century (3). These trends make clear the potential problems related to intergenerational transfers, both of the intrafamilial type and of the formal intercohort type.

Increases in life expectancies and in the percent and absolute number of older adults in a population also translate into changes in the family structure. It is projected that within the next 20 years that life expectancies will exceed 70 years for most of Latin America and the Caribbean. Life expectancy at age 60 has increased from 10 or 12 years in the 1950s to 20 years at present. This means that persons aged 60 today can expect to live about 8 more years than if they had been 60 years old in 1950 - and thus to spend 8 more years participating in the transfer system.

\section{INTRAFAMILIAL TRANSFERS}

The idyllic multigenerational family is largely a myth (4). Nevertheless, intergenerational exchange and mutuality-though not always conflictfree-is still a reality in Latin America and the Caribbean. In the past, a strong determinant of high fertility levels in traditional societies was the socalled old-age security motive. High fertility levels were maintained in order to ensure that when older members of a family or group were no longer able to work that they were supported by the younger members (5). ${ }^{2}$ In modern society, old-age security based on intrafamilial transfers depends not so much on the number of children as on such other factors as marital stability, availability of housing in the cities, the role of women in society, migration for employment, increased rates of unemployment, and economic instability.

However, decreases in fertility have led and will continue to lead to a decreased number of available caregivers for older adults. In most cultures women remain the primary caregivers for all generations, even when older sons are traditionally bound to care for their parents, as is the case in Southeast Asia. Meanwhile, women who have fewer siblings to share in their caregiving roles are increasingly working outside the home in the formal economy as well as inside the home. These women experience increasing demands in caregiving for both older and younger generations (6). Therefore, conflicts related to intrafamily transfers may be based on issues not just of generational equity but also of gender equity.

The importance of intergenerational exchanges and equity is shown by a multicenter project, the

\footnotetext{
2 Palloni A, De Vos S. Changes in families and households in Latin America, 1970-1990 [conference paper]. Population Association of America Meetings, Miami, Florida, 1994.
} 
TABLE 1. Intergenerational transfers for adults age 60 and older in seven cities of Latin America and the Caribbean, 2000

\begin{tabular}{|c|c|c|c|c|c|c|c|c|c|c|c|c|}
\hline \multirow[b]{3}{*}{ City } & \multicolumn{6}{|c|}{$\begin{array}{l}\text { Older adults who co-reside with their children } \\
\text { and who ... }\end{array}$} & \multicolumn{6}{|c|}{$\begin{array}{l}\text { Older adults who do not co-reside with their children } \\
\text { and who... }\end{array}$} \\
\hline & \multicolumn{3}{|c|}{ Give help (\%) } & \multicolumn{3}{|c|}{ Receive help (\%) } & \multicolumn{3}{|c|}{ Give help (\%) } & \multicolumn{3}{|c|}{ Receive help (\%) } \\
\hline & None & Money & Other & None & Money & Other & None & Money & Other & None & Money & Other \\
\hline Bridgetown & 39 & 29 & 32 & 34 & 37 & 29 & 83 & 6 & 11 & 70 & 15 & 15 \\
\hline Buenos Aires & 34 & 14 & 52 & 8 & 28 & 63 & 69 & 5 & 25 & 61 & 13 & 26 \\
\hline Havana & 40 & 16 & 44 & 32 & 29 & 38 & 82 & 5 & 13 & 58 & 22 & 19 \\
\hline Mexico City & 42 & 14 & 44 & 50 & 17 & 33 & 85 & 5 & 10 & 70 & 20 & 10 \\
\hline Montevideo & 12 & 45 & 43 & 26 & 34 & 40 & 74 & 6 & 20 & 69 & 8 & 23 \\
\hline Santiago & 33 & 16 & 51 & 57 & 16 & 27 & 90 & 3 & 7 & 77 & 8 & 15 \\
\hline São Paulo & 22 & 21 & 57 & 38 & 18 & 44 & 76 & 4 & 20 & 67 & 12 & 21 \\
\hline
\end{tabular}

a In the table, each of the respective groupings adds to a total of $100 \%$ because of the phrasing of the questions used with the older adults. The older adults were asked if they gave help to or received help from their children, and they then selected one of three categories: none, money, or "other." "Other" includes such things as help with housekeeping, transportation, and companionship.

Study on Aging, Health, and Well-being (Salud, Bienestar y Envejecimiento en América Latina, or Proyecto $S A B E)$. The SABE study was carried out in 2000 in seven major cities of Latin America and the Caribbean: Bridgetown, Buenos Aires, Havana, Mexico City, Montevideo, Santiago, and São Paulo (7). With the contributions of a number of other funding partners, collaborating centers, and universities throughout the Americas, the Pan American Health Organization (PAHO) coordinated a total of 10600 statistically selected interviews with people 60 years and older. This is the first time that comparable data have been collected on elders in Latin America and the Caribbean for the purpose of studying their health status and the determinants of health.

According to the SABE study, intergenerational family transfers are more evident when an older person lives in the same household with an adult child. The co-residing elder gives about the same amount of aid as he or she receives from the adult child and other younger members of that household. For elders who do not co-reside with their children, the degree of intergenerational transfers is much lower, but these elders are more likely to receive aid than to give it.

More importantly, the SABE data illustrate the degree and mutuality of exchange across generations in the surveyed cities (Table 1). The exchange is rarely strictly monetary. Older adults primarily receive from their children food and clothing, transportation, and such other services as help with housekeeping. Older adults also provide help to younger generations, including caregiving for the grandchildren, help with household chores, and some monetary aid.

To better understand intrafamily transfers in urban settings in Latin America and the Caribbean, three other facts highlighted by the SABE data are of interest. First, the portion of elders who live with their children varies in the seven urban areas (Table 2). Approximately 9 out of 10 persons age 60 and over have children. Of those with living children, approximately one-half of elders live with any of their children, with the exception of Mexico City, where the proportion is much higher. Second, the most important predictor for co-residing with a child is having lost a spouse. Third, the rate of solitary living among females 75+ is much higher than for males of any age.

We do not have very reliable data on the amount of abuse, neglect, and abandonment of disabled older persons committed by other family members in Latin America and the Caribbean. In theory, economic dependency and patterns of conflict established throughout life are good predictors of elder abuse or neglect. However, the

TABLE 2. Adults 60 and over in seven cities of Latin America and the Caribbean who have living children, and the residency status of those older adults with children, 2000

\begin{tabular}{lccc}
\hline City & $\begin{array}{c}\text { Older adults } \\
\text { who have } \\
\text { children } \\
(\%)\end{array}$ & $\begin{array}{c}\text { Older adults } \\
\text { with children } \\
\text { who co-reside } \\
\text { with them } \\
(\%)\end{array}$ & $\begin{array}{c}\text { Older adults } \\
\text { with children who } \\
\text { do not co-reside } \\
\text { with them } \\
(\%)\end{array}$ \\
\hline Bridgetown & 86 & 43 & 57 \\
Buenos Aires & 87 & 40 & 60 \\
Havana & 87 & 61 & 39 \\
Mexico City & 95 & 71 & 29 \\
Montevideo & 90 & 45 & 55 \\
Santiago & 91 & 61 & 39 \\
São Paulo & 90 & 52 & 48 \\
\hline
\end{tabular}


rapid growth of the private geriatric home market experienced in many LAC countries indicates that generational transfers at home are also predicated on the "mutuality" of the exchanges in old age. When the disabled older person is no longer capable of contributing, the intrafamily system of care breaks down and the older person may be "housed" elsewhere for a fee that the children pay.

\section{INTERCOHORT SYSTEMS OF TRANSFERS}

In most countries of Latin America and the Caribbean, pension payments are just one component of general social security schemes, which often include health payments to persons of all ages. Traditionally, pension systems have been associated with transfers made through so-called "pay-as-you-go" schemes, which have prevailed in combination with intrafamily transfers. This approach has lacked solvency and has protected a very small number of older persons.

A minority of older adults in Latin America and the Caribbean have access to social security. This is especially true for women and the poor. Pension and retirement coverage is also very uncommon, and the coverage that does exist is rarely sufficient to meet the basic necessities of life. Fewer than half of persons aged 60 and older who live in LAC urban areas are beneficiaries of social security. In rural areas the coverage rates are even worse, just some $10 \%$, except in the case of Brazil, which does have high rates of coverage in rural sections. Low social security coverage contributes to the relatively higher rates of informal labor force participation among older adults. The participation rate in Latin America and the Caribbean is 30\% overall, but among men it ranges as high as $60 \%$ (8).

It is doubtful, moreover, that "pay-as-you-go" pension systems can provide equitable distribution of wealth for all generations, for three major reasons.

One reason is the drastic increase that has occurred in the ratio of older persons to workers as a result of past demographic trends. This pattern will increasingly challenge the solvency of pension systems and will also leave little hope for those who will turn 60 and hope to retire from work over the next two decades.

A second reason is that life expectancy at age 60 continues to rise, thereby increasing the expected length of time to be spent in retirement. In combination with the rapid growth in the number of persons who join the ranks of elders every year, this will further test the already-fragile pension systems.

A third reason concerns life expectancy and disability. While life expectancy has been increasing in Latin America and the Caribbean, there has not been a commensurate increase in the number of years that older persons can expect to live disability-free.

Given these trends, it is likely that the rising costs for pensions, health care, and long-term care will challenge any traditional form of intercohort pension scheme. It is doubtful that the growing ranks of older persons will find a secure future unless all the various forms of intergenerational solidarity are strengthened.

What are the feasible alternatives for an equitable system of transfers? The current intrafamilial transfer system could continue to operate to some extent, but it will require new and creative mechanisms of support as well as a major commitment to providing more targeted services for maintaining health and function in older age. Moreover, new private capitalization mechanisms for pension programs will require a transitional period of at least 20 years, making these programs unrealistic for the very large number of persons who will be joining the ranks of persons 60 and older within the next decade. In addition, these private schemes continue to leave out the most vulnerable of older adults, including women, persons with disabilities, and those who are working in the informal sector.

The path to intergenerational equity will vary from country to country, depending on the roles that families and governments take in advocating and providing for social support and equity. Data from numerous countries have shown that collectivist social welfare policies that govern family benefits are critical in buffering economic turbulence and in providing structural support for family maintenance (9). However, these policies must take into consideration the intergenerational exchanges for the $10 \%$ of the older adult population who do not have children.

Intergenerational equity requires investing in all ages. Older adults must be supported in order to empower themselves and others. The SABE survey indicated that there is a healthy mutuality of exchange between the generations for a fraction of the urban population in Latin America and the Caribbean. As long as they are able to function, these grandparents are an integral and vital part of the family unit. They provide not only invaluable caregiving duties but also a sense of identity and continuity. At the same time, they receive from the younger family members basic support that enables them to cope with their restricted financial situation.

Nevertheless, in spite of intrafamilial transfers, approximately one in every two elders in the SABE survey reported not having enough money to meet their basic daily needs. Therefore, in order to enable older persons to live a dignified old age, a multisectorial response is urgently needed. The 
health sector must better manage the complex health problems related to old age, through such strategies as strengthening the capacity of the primary health care level to promote and protect the health of elders. The education sector must assume responsibility for lifelong learning and must be retooled to help keep older persons integrated into the labor force. The labor and economic sectors must guarantee against age discrimination and must support intergenerational microenterprise loans. Along with the general social structure, the legal system must provide guarantees and incentives to maintain older persons integrated into the society. The human and civil rights of older persons must be recognized, and elders must have legal recourse in cases of abuse or neglect. Given the rapid aging of the population in Latin America and the Caribbean, promoting equity in intergenerational transfers is both an economic imperative and an ethical mandate.

\section{SINOPSIS}

\section{Equidad y sistemas de transferencia intergeneracional en América Latina y el Caribe}

Las transferencias intergeneracionales deben formar parte de la discusión sobre la equidad en el contexto del rápido en- vejecimiento de la población de América Latina y el Caribe $(A L C)$, especialmente alli donde los recursos sean escasos. Aunque hay datos que muestran la existencia de cierto grado de intercambio entre las viejas y las nuevas generaciones, el número creciente de adultos en comparación con las personas más jóvenes puede crear tensiones en esta relación. El número de personas de 60 años o más aumentará en los países de ALC de 42 millones en el año 2000 a 97 millones en el 2025 y a 181 millones en el 2050. Como proporción de la población total, el crecimiento será del $8 \%$ en el año 2000 del $14 \%$ en el 2025 y del $23 \%$ en el 2050 . Este crecimiento creará una tensión sin precedentes en las familias, así como en los sistemas de seguridad social, los servicios de salud y otros servicios sociales. A medida que aumente la incapacidad de las familias para hacer frente a las necesidades económicas y sociales del número creciente de ancianos, habrá una demanda cada vez mayor de mecanismos formales de apoyo entre cohortes, tales como los sistemas de seguridad social y los programas de pensiones. Sin embargo, estos mecanismos son inexistentes o insolventes en muchas naciones de ALC. Una posible solución, la capitalización privada de los programas de pensiones, necesitaría más de dos décadas para ser viable y dejaría fuera a los segmentos más vulnerables de la población, como los que trabajan en el sector informal. Dadas estas tendencias, los derechos e intereses de los ancianos deben incorporarse cada vez más a las agendas políticas, sociales y económicas de los países de ALC.

\section{REFERENCES}

1. Palloni A, De Vos S, Pelaez M. Aging in Latin America and the Caribbean. Madison, Wisconsin, United States of America: Center for Demography and Ecology, University of Wisconsin-Madison; 1999. (CDE Working Paper No. 99-02).

2. United Nations. World population ageing, 1950-2050. New York: United Nations, 2002

3. Palloni A, Pelaez M. Demographic and health conditions of aging in Latin America and the Caribbean. Int J Epidemiol. Forthcoming 2002.
4. Jefferys M. Cultural aspects of ageing: gender and inter-generational issues. Soc Sci Med 1996;43(5):681-687.

5. Caldwell J. Theory of fertility decline. New York: Academic Press; 1982.

6. Katz Olson L. The graying of the world: who will care for the frail elderly? New York: Haworth Press; 1994.

7. Pelaez M, Palloni A. Preliminary report of the SABE survey. Washington, D.C.: Pan American Health Organization; 2001.

8. Centro Latinoamericano y Caribeño de Demografía. Los adultos mayores en
América Latina y el Caribe: datos e indicadores. Santiago, Chile: CELADE, División de Población; 2002.

9. O'Rand A. Stratification of the life course. In: RH Binstock RH, George LK, eds. Handbook of aging and the social sciences. New York: Academic Press, 1996. Pp. 188-207. 